\title{
LEVEL II SCOUR ANALYSIS FOR BRIDGE 20 (IRASTH00080020) on TOWN HIGHWAY 8, crossing the BLACK RIVER, IRASBURG, VERMONT
}

U.S. Geological Survey Open-File Report 96-154

Prepared in cooperation with

VERMONT AGENCY OF TRANSPORTATION and

FEDERAL HIGHWAY ADMINISTRATION 


\section{LEVEL II SCOUR ANALYSIS FOR BRIDGE 20 (IRASTH00080020) on TOWN HIGHWAY 8, crossing the BLACK RIVER, \\ IRASBURG, VERMONT \\ By SCOTT A. OLSON}

U.S. Geological Survey

Open-File Report 96-154

Prepared in cooperation with

VERMONT AGENCY OF TRANSPORTATION

and

FEDERAL HIGHWAY ADMINISTRATION 


\title{
U.S. DEPARTMENT OF THE INTERIOR BRUCE BABBITT, Secretary
}

\author{
U.S. GEOLOGICAL SURVEY \\ Gordon P. Eaton, Director
}

For additional information write to:

District Chief

U.S. Geological Survey 361 Commerce Way

Pembroke, NH 03275-3718
Copies of this report may be purchased from:

U.S. Geological Survey Earth Science Information Center Open-File Reports Section Box 25286, MS 517 Federal Center

Denver, CO 80225 


\section{CONTENTS}

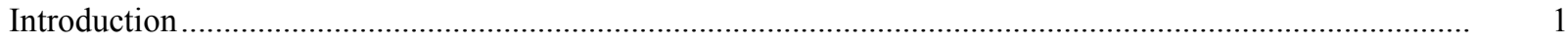

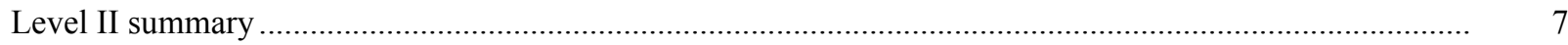

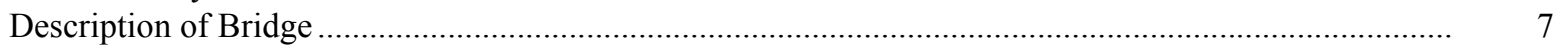

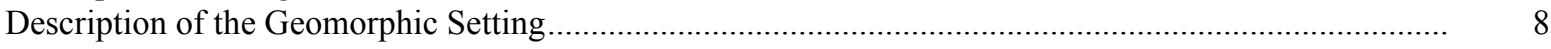

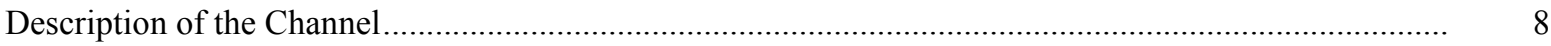

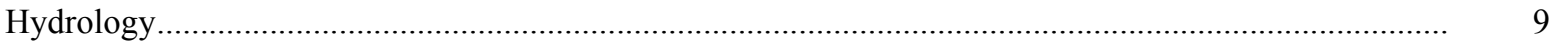

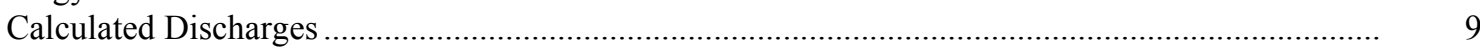

Description of the Water-Surface Profile Model (WSPRO) Analysis ......................................................... 10

Cross-Sections Used in WSPRO Analysis ......................................................................................

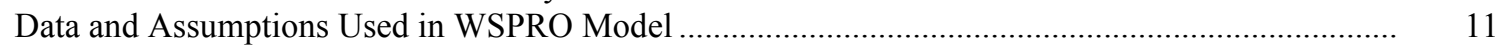

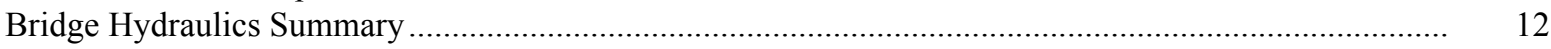

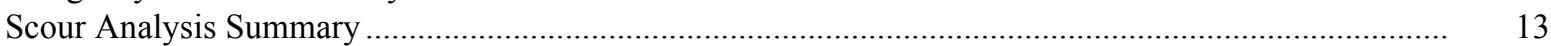

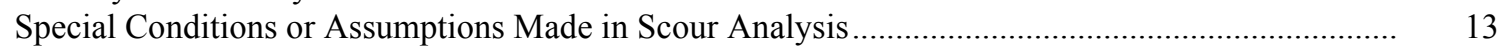

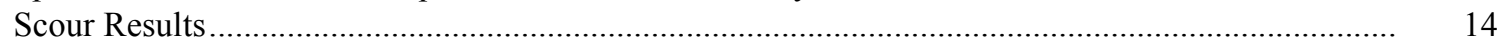

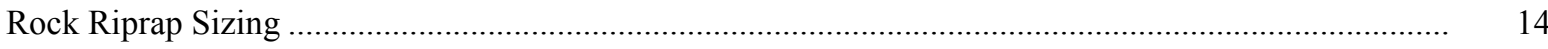

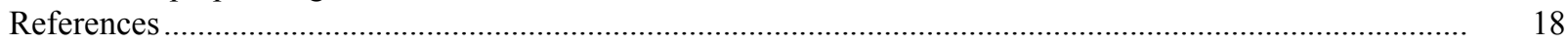

Appendixes:

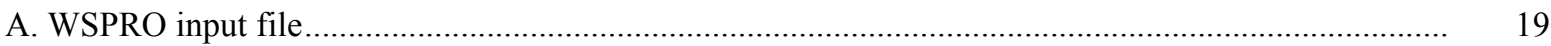

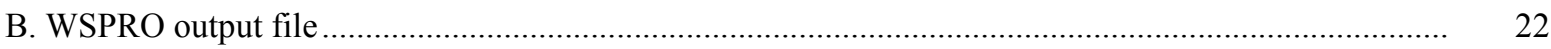

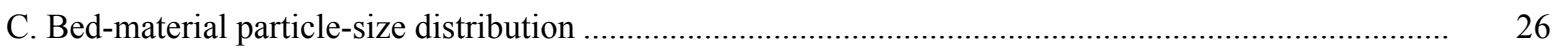

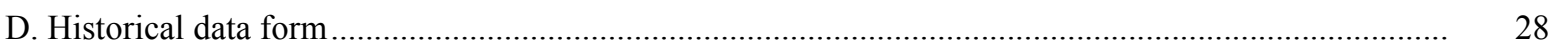

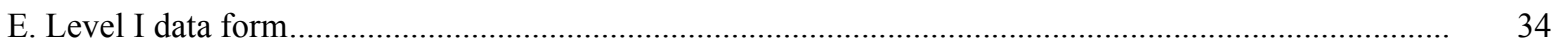

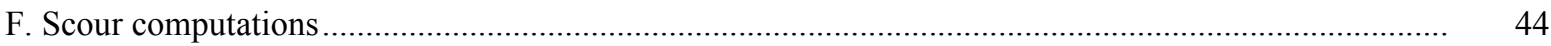

\section{FIGURES}

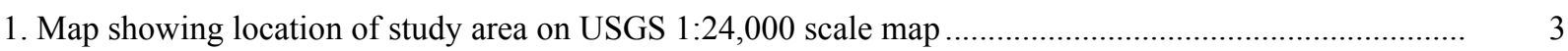

2. Map showing location of study area on Vermont Agency of Transportation town

highway map ................................................................................................................. 4

3. Structure IRASTH00080020 viewed from upstream $($ October 4, 1994) ……............................................ 5

4. Downstream channel viewed from structure IRASTH00080020 (October 4, 1994)................................. 5

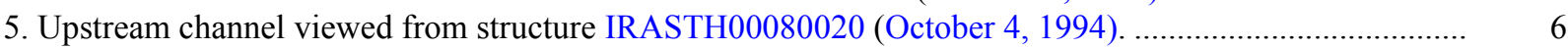

6. Structure IRASTH00080020 viewed from downstream (October 4, 1994) .............................................. 6

7. Water-surface profiles for the 100- and 500-year discharges at structure
IRASTH00080020 on Town Highway 8, crossing the Black River, Irasburg, Vermont................

8. Scour elevations for the 100 - and 500-year discharges at structure

IRASTH00080020 on Town Highway 8, crossing the Black River, Irasburg, Vermont................ 16

\section{TABLES}

1. Remaining footing/pile depth at abutments for the 100-year discharge at structure

IRASTH00080020 on Town Highway 8, crossing the Black River, Irasburg, Vermont ................... 17

2. Remaining footing/pile depth at abutments for the 500-year discharge at structure

IRASTH00080020 on Town Highway 8, crossing the Black River, Irasburg, Vermont ................... 


\begin{tabular}{|c|c|c|}
\hline Multiply & By & To obtain \\
\hline \multicolumn{3}{|c|}{ Length } \\
\hline inch (in.) & 25.4 & millimeter (mm) \\
\hline foot $(\mathrm{ft})$ & 0.3048 & meter $(\mathrm{m})$ \\
\hline mile (mi) & 1.609 & kilometer (km) \\
\hline \multicolumn{3}{|c|}{ Slope } \\
\hline foot per mile ( $\mathrm{ft} / \mathrm{mi})$ & 0.1894 & meter per kilometer $(\mathrm{m} / \mathrm{km})$ \\
\hline \multicolumn{3}{|c|}{ Area } \\
\hline square mile $\left(\mathrm{mi}^{2}\right)$ & 2.590 & square kilometer $\left(\mathrm{km}^{2}\right)$ \\
\hline \multicolumn{3}{|c|}{ Volume } \\
\hline cubic foot $\left(\mathrm{ft}^{3}\right)$ & $\begin{array}{l}0.02832 \\
\text { Velocity and Flow }\end{array}$ & cubic meter $\left(\mathrm{m}^{3}\right)$ \\
\hline foot per second (ft/s) & 0.3048 & meter per second $(\mathrm{m} / \mathrm{s})$ \\
\hline cubic foot per second $\left(\mathrm{ft}^{3} / \mathrm{s}\right)$ & 0.02832 & cubic meter per second $\left(\mathrm{m}^{3} / \mathrm{s}\right)$ \\
\hline $\begin{array}{l}\text { cubic foot per second per } \\
\text { square mile } \\
{\left[\left(\mathrm{ft}^{3} / \mathrm{s}\right) / \mathrm{mi}^{2}\right]}\end{array}$ & 0.01093 & $\begin{array}{l}\text { cubic meter per } \\
\text { second per square } \\
\text { kilometer }\left[\left(\mathrm{m}^{3} / \mathrm{s}\right) / \mathrm{km}^{2}\right]\end{array}$ \\
\hline
\end{tabular}

OTHER ABBREVIATIONS

$\begin{array}{lrlr}\mathrm{BF} & \text { bank full } & \text { LWW } & \text { left wingwall } \\ \mathrm{cfs} & \text { cubic feet per second } & \text { MC } & \text { main channel } \\ \mathrm{D}_{50} & \text { median diameter of bed material } & \text { RAB } & \text { right abutment } \\ \mathrm{DS} & \text { downstream } & \text { RABUT } & \text { face of right abutment } \\ \mathrm{elev} & \text { elevation } & \text { RB } & \text { right bank } \\ \mathrm{f} / \mathrm{p} & \text { flood plain } & \text { ROB } & \text { right overbank } \\ \mathrm{ft} & \text { square feet } & \text { RWW } & \text { right wingwall } \\ \mathrm{ft} / \mathrm{ft} & \text { feet per foot } & \text { TH } & \text { town highway } \\ \mathrm{JCT} & \text { junction } & \text { UB } & \text { under bridge } \\ \mathrm{LAB} & \text { left abutment } & \text { US } & \text { upstream } \\ \mathrm{LABUT} & \text { face of left abutment } & \text { USGS } & \text { United States Geological Survey } \\ \text { LB } & \text { left bank } & \text { VTAOT Vermont Agency of Transportation } \\ \text { LOB } & \text { left overbank } & \text { WSPRO } & \text { water-surface profile model }\end{array}$

In this report, the words "right" and "left" refer to directions that would be reported by an observer facing downstream. Sea level: In this report, "sea level" refers to the National Geodetic Vertical Datum of 1929-- a geodetic datum derived from a general adjustment of the first-order level nets of the United States and Canada, formerly called Sea Level Datum of 1929.

In the appendices, the above abbreviations may be combined. For example, USLB would represent upstream left bank. 


\title{
LEVEL II SCOUR ANALYSIS FOR BRIDGE 20 (IRASTH00080020) ON TOWN HIGHWAY 8, CROSSING THE BLACK RIVER, IRASBURG, VERMONT
}

\author{
By Scott A. Olson
}

\section{INTRODUCTION}

This report provides the results of a detailed Level II analysis of scour potential at structure IRASTH00080020 on town highway 8 crossing the Black River, Irasburg, Vermont (figures 1-8). A Level II study is a basic engineering analysis of the site, including a quantitative analysis of stream stability and scour (U.S. Department of Transportation, 1993). A Level I study is included in Appendix E of this report. A Level I study provides a qualitative geomorphic characterization of the study site. Information on the bridge, available from VTAOT files, was compiled prior to conducting Level I and Level II analyses and can be found in Appendix D.

The site is in the New England Upland physiographic province of north-central Vermont in the town of Irasburg. The $110-\mathrm{mi}^{2}$ drainage area is in a predominantly rural basin. In the vicinity of the study site, the left bank surface cover is pasture and row crops and the right bank is covered by shrub and brush and is adjacent to woods.

In the study area, the Black River has a sinuous channel with a slope of approximately $0.002 \mathrm{ft} / \mathrm{ft}$, an average channel top width of $90 \mathrm{ft}$ and an average channel depth of $5 \mathrm{ft}$. The predominant channel bed material is gravel and cobbles ( $D_{50}$ is $49.7 \mathrm{~mm}$ or $0.163 \mathrm{ft}$ ). The geomorphic assessment at the time of the Level I and Level II site visit on October 4, 1994, indicated that the reach was laterally unstable. 
The town highway 8 crossing of the Black River is a 88 -ft-long, one-lane covered bridge consisting of one 80-foot span (Vermont Agency of Transportation, written commun., August 2, 1994). The bridge is supported by vertical, concrete abutments with wingwalls on the upstream and downstream sides of the right abutment. The right abutment has stone fill protection. The channel is skewed approximately 25 degrees to the opening while the opening-skew-to-roadway is zero degrees. Additional details describing conditions at the site are included in the Level II Summary and Appendices D and E.

Scour depths and rock rip-rap sizes were computed using the general guidelines described in Hydraulic Engineering Circular 18 (Richardson and others, 1993). Scour depths were calculated assuming an infinite depth of erosive material and a homogeneous particle-size distribution. The scour analysis results are presented in tables 1 and 2 and a graph of the scour depths is presented in figure 8 . 


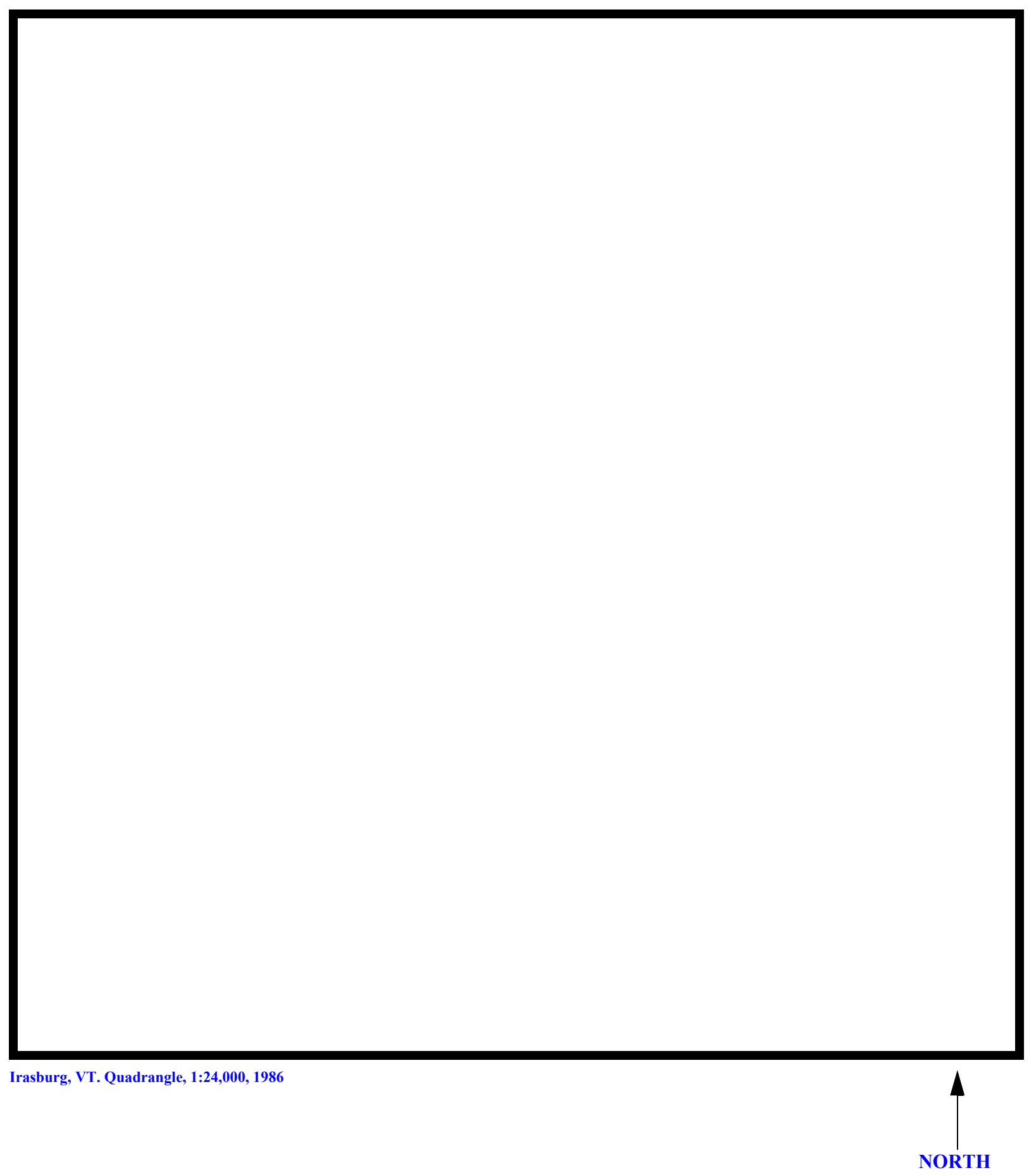

Figure 1. Location of study area on USGS 1:24,000 scale map. 
Figure 2. Location of study area on Vermont Agency of Transportation town highway map. 

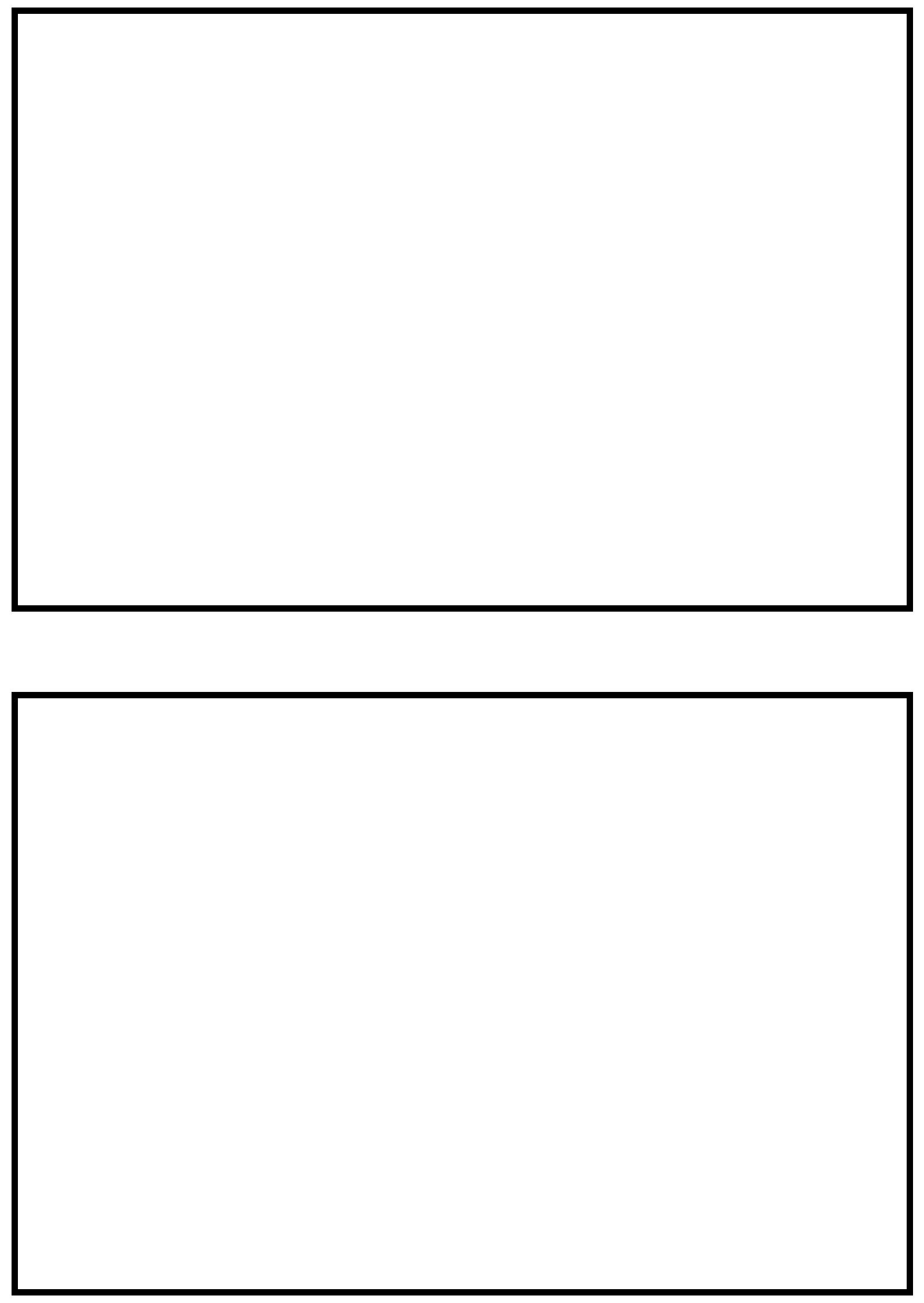

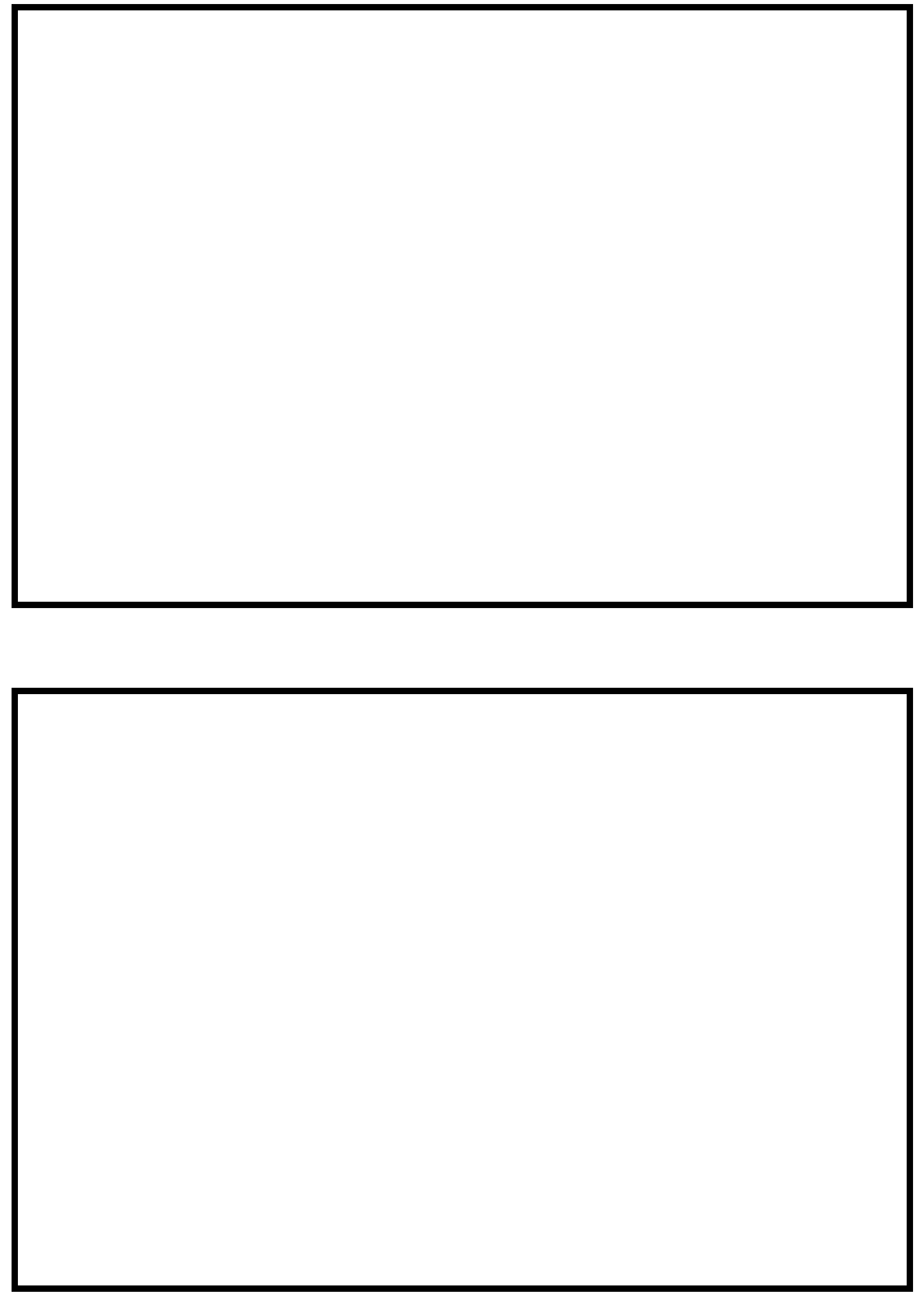


\section{LEVEL II SUMMARY}

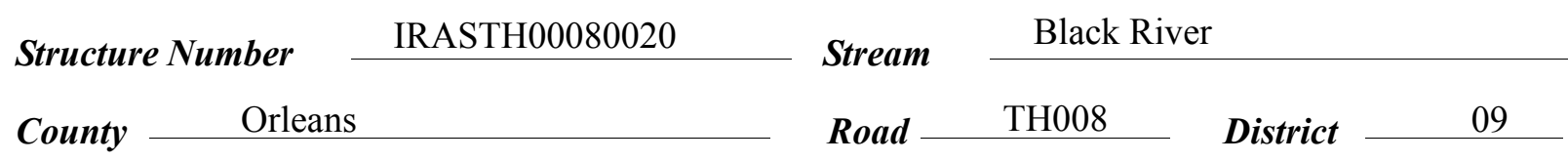

\section{Description of Bridge}

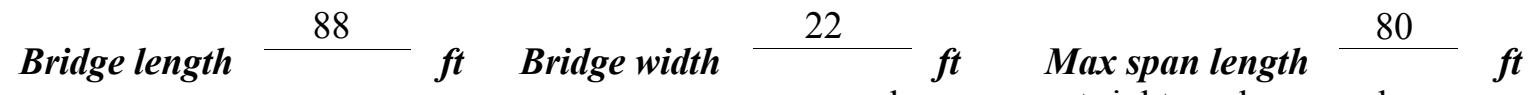
Alignment of bridge to road (on curve or straight) Abutment type Concrete, vertical

Stone fill on abutment? on right Embankment type sharp curve at right road approach

nasmintina.. of atoms fill Mato af incmortinn
Type-2 stone fill on right abutment, upstream right wingwall, and the upstream and downstream sides of the right road approach. Type-3 stone fill on upstream side of the left road approach.

Is bridge skewed to flood flow according to $\mathrm{Y} \quad$ 'survey?
The river severely curves at the approach to the bridge. This curve results in a skew of 25_degrees
and in the flow impacting the right abutment also at approximately 25 degrees.

Debris accumulation on bridge at time of Level I or Level II site visit:

\begin{tabular}{|c|c|c|c|}
\hline & $\begin{array}{c}\text { Date of insnortion } \\
10 / 4 / 94 \\
\end{array}$ & $\begin{array}{l}\text { Percent of olommont } \\
\text { blocked hortzontatly }\end{array}$ & $\begin{array}{l}\text { Percent of } 0 \\
\text { blocked verticatty }\end{array}$ \\
\hline Level I & $10 / 4 / 94$ & -- & -- \\
\hline $\begin{array}{l}\text { Level II } \\
\text { of the bridge. }\end{array}$ & \multicolumn{3}{|c|}{ Accumulation potential is moderate due to sharp bend just upstream } \\
\hline
\end{tabular}

On 10/4/94 it was noted that flood flows will impact the right abutment heavily and may cause Doscriho anv, foaturos noar ar at tho hridoo that mav, affort flow, (includo ahsorvation dato ). pile-up of water and increase scour. 


\section{Description of the Geomorphic Setting}

General topography Moderate relief valley with wide flood plains and no apparent incision of the channel.

Geomorphic conditions at bridge site: downstream (DS), upstream (US)

Date of inspection $\quad 10 / 4 / 94$

DS left: $\quad$ wide flood plain

DS right: $\quad$ steep valley wall

US left: $\quad$ two-lane gravel road, then wide flood plain

US right: $\quad$ narrow flood plain, then steep valley wall

\section{Description of the Channel}

\begin{tabular}{lllll} 
Average top width & \multicolumn{9}{c}{ fo } & Average depth & $\frac{5}{\text { cobble }}$ \\
Predominant bed material & gravel & Bank material & sinuous, with flood
\end{tabular}

plains. Stream boundaries are alluvial and semi-alluvial and are laterally unstable

$10 / 4 / 94$

Vegetative co 1 Pasture and row crops

DS left: $\quad$ Shrub and brush with forest further from river

DS right: $\quad$ Pasture

US left: $\quad$ Shrub and brush

US right: $\quad \underline{\mathrm{N}}$

Do banks appear stable? 10/4/94--In the downstream channel a cut-bank is noted along the left date of observatton.

08/16/94--None

Describe any obstructions in channel and date of observation. 


\title{
Hydrology
}

Drainage area $\frac{110}{m i^{2}}$

Percentage of drainage area in physiographic provinces: (approximate)

Physiographic province New England Upland
Percent of drainage area 100

\begin{abstract}
Is drainage area considered rural or urban?
Rural urbanization: None

Describe any significant
\end{abstract}

Is there a USGS gage on the stream of interest?

USGS gage description

Yes

Black River at Coventry, Vermont

04296000

USGS gage number

122

Gage drainage area $\mathrm{mi}^{2}$

No

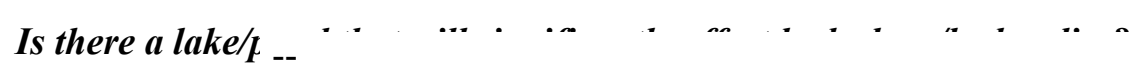

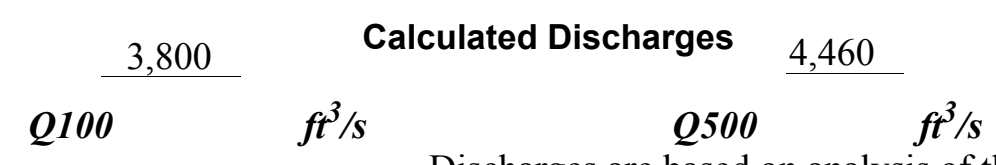

Discharges are based on analysis of the continuous

record from the Black River gage. The computed 100-year and 500-year discharges at the gage were reduced by a drainage area relationship [(110/122) to the 0.8 power] to determine the discharges at the bridge site. 


\section{Description of the Water-Surface Profile Model (WSPRO) Analysis}

Datum for WSPRO analysis (USGS survey, sea level, VTAOT plans)

USGS survey

Datum tie between USGS survey and VTAOT plans

Add 265.4 feet to VTAOT datum.

RM1 is a chiseled $\mathbf{X}$ on top of the downstream end of the left abutment wall with an arbitrary

Description of reference marks used to determine USGS datum. $\quad$ survey elevation of

1008.62 feet.

\section{Cross-Sections Used in WSPRO Analysis}

\begin{tabular}{cccl}
\hline${ }^{1}$ Cross-section & $\begin{array}{c}\text { Section } \\
\text { Reference } \\
\text { Distance } \\
(\text { SRD) } \text { in feet }\end{array}$ & $\begin{array}{c}{ }^{2} \text { Cross-section } \\
\text { development }\end{array}$ & \multicolumn{1}{c}{ Comments } \\
\hline EXIT2 & -121 & 1 & Downstream section \\
EXIT1 & -39 & 1 & Exit section \\
FV & 0 & 2 & $\begin{array}{l}\text { Downstream Full-valley } \\
\text { section (Templated from } \\
\text { EXIT1) } \\
\text { BRIDG }\end{array}$ \\
RDWAY & 0 & 1 & Bridge section \\
APPR1 & 10 & 1 & Road Grade section \\
& 110 & 1 & Approach section \\
\hline
\end{tabular}

${ }^{1}$ For location of cross-sections see plan-view sketch included with Level I field form, Appendix E. For more detail on how cross-sections were developed see WSPRO input file. 


\section{Data and Assumptions Used in WSPRO Model}

Hydraulic analyses of the reach were done by use of the Federal Highway Administration's WSPRO step-backwater computer program (Shearman and others, 1986, and Shearman, 1990). Results of the hydraulic model are presented in the Bridge Hydraulic Summary, Appendix B, and figure 7.

Channel roughness factors (Manning's " $\mathrm{n}$ ") used in the hydraulic model were estimated using field inspections at each cross section following the general guidelines described by Arcement, Jr. and Schneider (1989). Final adjustments to the values were made during the modelling of the reach. Channel " $\mathrm{n}$ " values for the reach ranged from 0.040 to 0.045 , and overbank " $\mathrm{n}$ " values ranged from 0.035 to 0.095 .

Normal depth was assumed at the downstream-most section (EXIT2) for the starting water surface. This depth was computed by use of the slope-conveyance method outlined in

the User's manual for WSPRO (Shearman, 1990). The slope used was $0.0005 \mathrm{ft} / \mathrm{ft}$ which was water-surface slope on the day of the field inspection.

The modeled 100- and 500-year discharges did not overtop the roadway embankments or the bridge deck. 


\section{Bridge Hydraulics Summary}

$\begin{array}{lll}\text { Average bridge embankment elevation } & 1008.0 \\ \text { Average low steel elevation } & 1005.1 & \boldsymbol{f t}\end{array}$

100-year discharge $\quad 3,800 \quad \mathrm{ft}^{3} / \mathrm{s}$

Water-surface elevation in bridge opening $\quad 1000.5 f t$

Road overtopping? __ no Discharge over road ___ _- , s

Area of flow in bridge opening $\quad 526 \quad \mathrm{ft}^{2}$

Average velocity in bridge opening $\quad \begin{array}{ll}7.23 \\ \mathrm{ft}\end{array} \mathrm{s}$

Maximum WSPRO tube velocity at bridge $\quad 9.11 \mathrm{ft} / \mathrm{s}$

Water-surface elevation at Approach section with bridge 1001.6

Water-surface elevation at Approach section without bridge $\quad 1000.9$

Amount of backwater caused by bridge $\quad 0.7 \quad$ it

500-year discharge $\quad 4,460 \quad \mathrm{ft}^{3} / \mathrm{s}$

Water-surface elevation in bridge opening $\quad 1000.8 \mathrm{ft}$

Road overtopping? __ no Discharge over road __ _ _

Area of flow in bridge opening $\quad 542 \quad \mathrm{ft}^{2}$

Average velocity in bridge opening $\quad 8.23 \mathrm{ft} / \mathrm{s}$

Maximum WSPRO tube velocity at bridge 10.38 's

Water-surface elevation at Approach section with bridge 1002.3

Water-surface elevation at Approach section without bridge

Amount of backwater caused by bridge

1.1 .

Incipient overtopping discharge ___ -- $\mathrm{ft}^{3} / \mathrm{s}$

Water-surface elevation in bridge opening $\quad--\quad$ it

Area of flow in bridge opening

$-f^{2}$

Average velocity in bridge opening

Maximum WSPRO tube velocity at bridge $f t / s$

${ }_{--}^{-} f t / s$

Water-surface elevation at Approach section with bridge

Water-surface elevation at Approach section without bridge

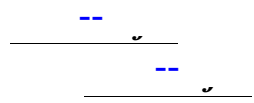
Amount of backwater caused by bridge

$-{ }_{-}^{-} i$ 


\section{Scour Analysis Summary}

\section{Special Conditions or Assumptions Made in Scour Analysis}

Scour depths were computed using the general guidelines described in Hydraulic Engineering Circular 18 (Richardson and others, 1993). Scour depths were calculated assuming an infinite depth of erosive material and a homogeneous particle-size distribution. The results of the scour analysis are presented in tables 1 and 2 and a graph of the scour depths is presented in figure 8 .

Contraction scour was computed by use of the clear-water contraction scour equation (Richardson and others, 1993, p. 35, equation 18). For contraction scour computations, the average depth in the contracted section (AREA/TOPWIDTH) is subtracted from the depth of flow computed by the scour equation (Y2) to determine the actual amount of scour.

Abutment scour for the left abutment was computed by use of the Froehlich equation (Richardson and others, 1993, p. 49, equation 24). The Froehlich equation gives "excessively conservative estimates of scour depths" (Richardson and others, 1993, p. 48). Variables for the Froehlich equation include the Froude number of the flow approaching the embankments, the length of the embankment blocking flow, and the depth of flow approaching the embankment less any roadway overtopping.

Scour at the right abutment was computed by use of the HIRE equation (Richardson and others, 1993, p. 50, equation 25) because the HIRE equation is recommended when the length to depth ratio of the embankment blocking flow exceeds 25. Variables for the HIRE abutment scour equation are the same as the Froehlich abutment scour equation. 


\section{Scour Results}

100-yr discharge 500-yr discharge

Incipient
overtopping
discharge

Contraction scour:

(Scour depths in feet)

Main channel

Live-bed scour

Clear-water scour

Depth to armoring

Left overbank

Right overbank

Local scour:

Abutment scour

Left abutment

Right abutment

Pier scour

Pier 1

Pier 2

Pier 3
15.9

13.5
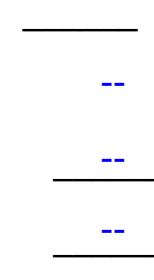

17.3

14.8
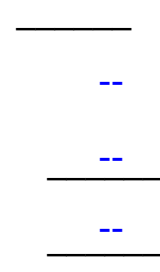

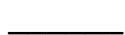

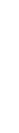




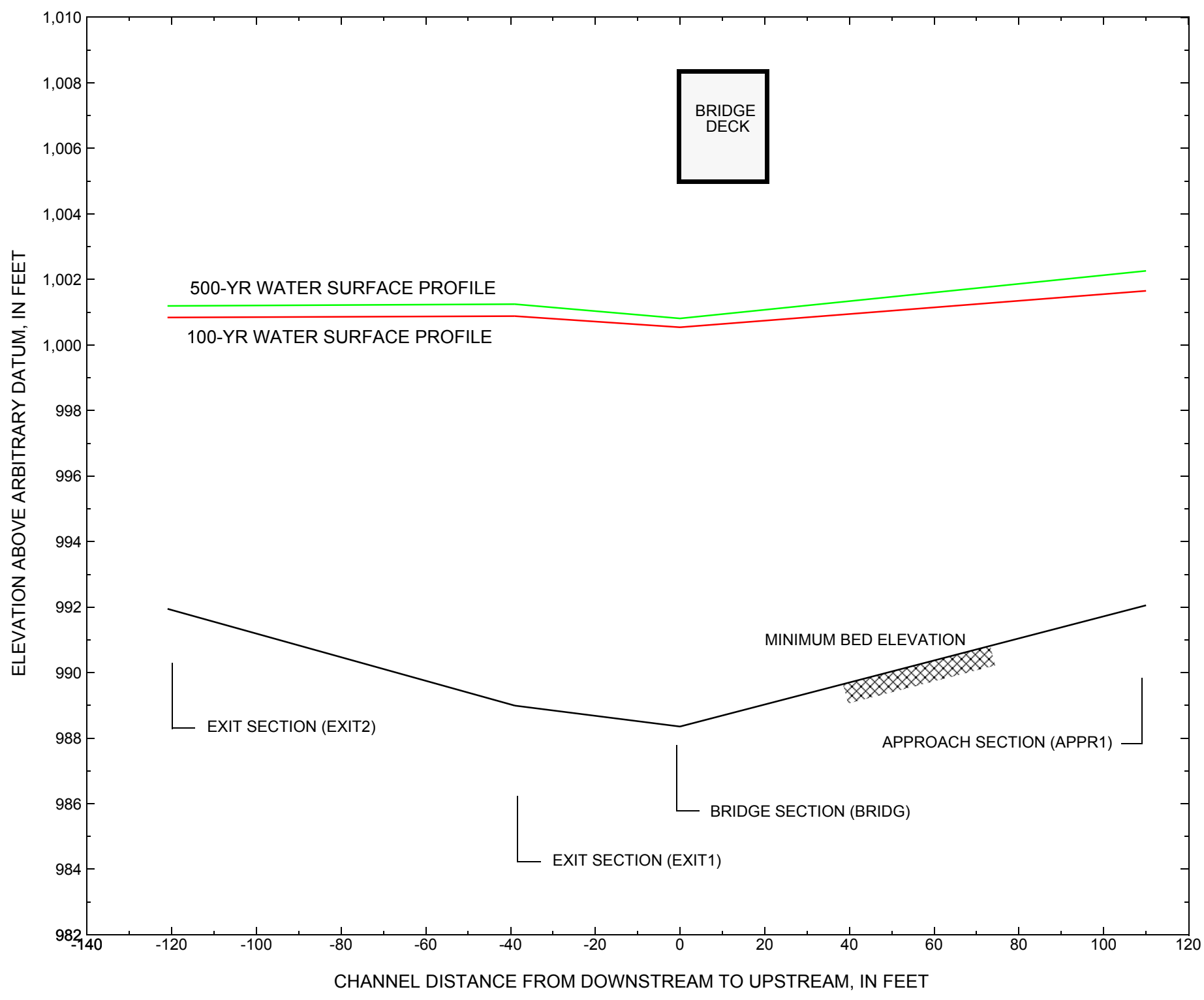

Figure 7. Water-surface profiles for the 100- and 500-yr discharges at structure IRASTH00080020 on town highway 8, crossing the Black River, Irasburg, Vermont. 


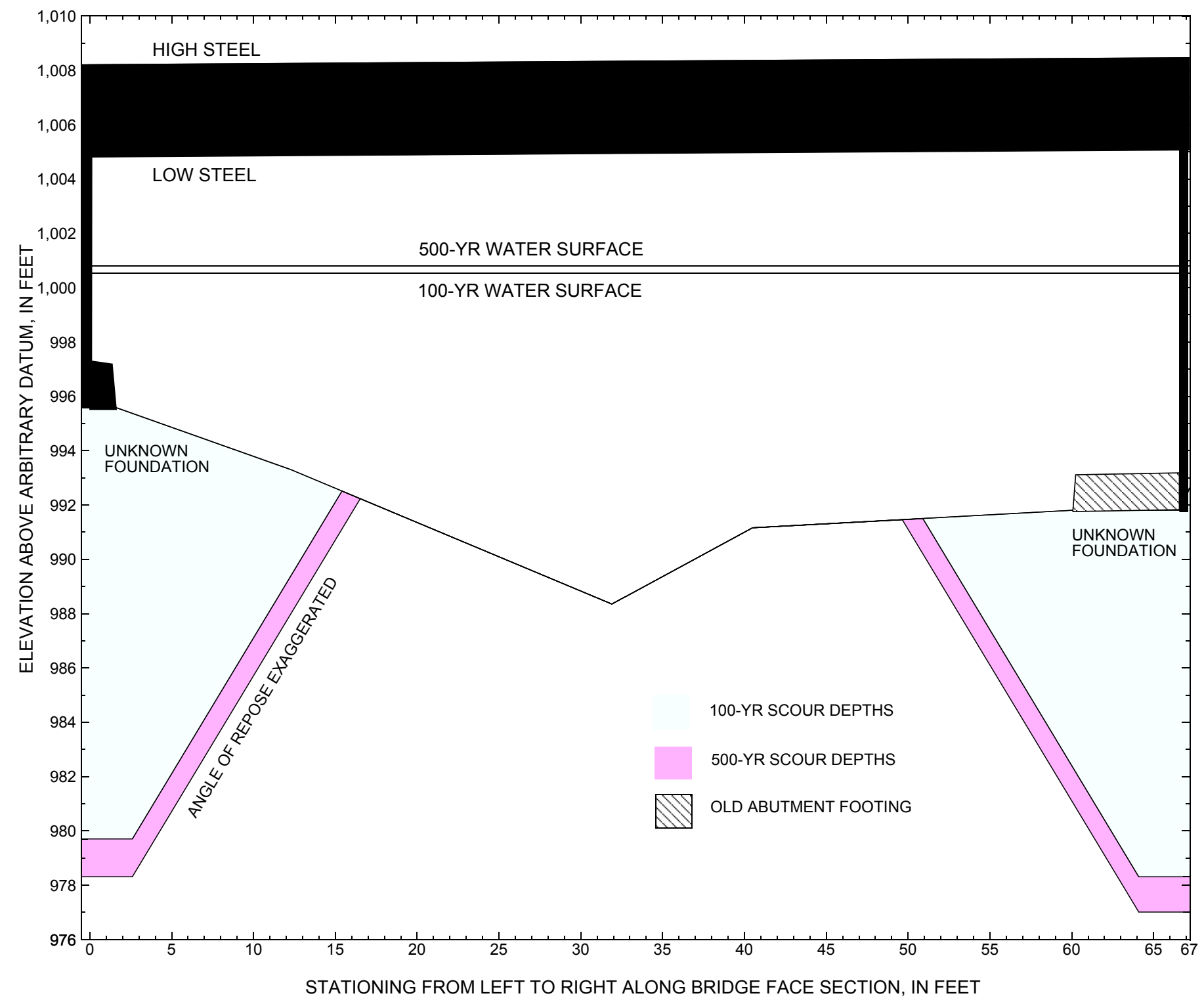

Figure 8. Scour elevations for the 100-yr and 500-yr discharges at structure IRASTH00080020 on town highway 8, crossing the Black River, Irasburg, Vermont. 
Table 1. Remaining footing/pile depth at abutments for the 100-year discharge at structure IRASTH00080020 on Town Highway 8, crossing the Black River, Irasburg, Vermont.

[VTAOT, Vermont Agency of Transportation; --,no data]

\begin{tabular}{|c|c|c|c|c|c|c|c|c|c|c|c|}
\hline Description & Station $^{1}$ & $\begin{array}{l}\text { VTAOT } \\
\text { minimum } \\
\text { low-chord } \\
\text { elevation } \\
\text { (feet) }\end{array}$ & $\begin{array}{l}\text { Surveyed } \\
\text { minimum } \\
\text { low-chord } \\
\text { elevation } \\
\text { (feet) }\end{array}$ & $\begin{array}{c}\text { Bottom of } \\
\text { footing } \\
\text { elevation } \\
\text { (feet) }\end{array}$ & $\begin{array}{l}\text { Channel } \\
\text { elevation at } \\
\text { abutment/ } \\
\text { pier }^{2} \\
\text { (feet) }\end{array}$ & $\begin{array}{l}\text { Contraction } \\
\text { scour depth } \\
\text { (feet) }\end{array}$ & $\begin{array}{l}\text { Abutment } \\
\text { scour } \\
\text { depth } \\
\text { (feet) }\end{array}$ & $\begin{array}{l}\text { Pier } \\
\text { scour } \\
\text { depth } \\
\text { (feet) }\end{array}$ & $\begin{array}{l}\text { Depth of } \\
\text { total scour } \\
\text { (feet) }\end{array}$ & $\begin{array}{c}\text { Elevation of } \\
\text { scour }^{2} \\
\text { (feet) }\end{array}$ & $\begin{array}{c}\text { Remaining } \\
\text { footing/pile } \\
\text { depth } \\
\text { (feet) }\end{array}$ \\
\hline \multicolumn{12}{|c|}{100 -yr. discharge is 3,800 cubic-feet per second } \\
\hline Left abutment & 0.0 & 739.4 & 1004.8 & -- & 995.6 & 0.0 & 15.9 & -- & 15.9 & 979.7 & -- \\
\hline Right abutment & 66.7 & -- & 1005.3 & -- & 991.8 & 0.0 & 13.5 & -- & 13.5 & 978.3 & -- \\
\hline
\end{tabular}

1. Measured along the face of the most constricting side of the bridge.

2. Arbitrary datum for this study.

Table 2. Remaining footing/pile depth at abutments for the 500-year discharge at structure IRASTH00080020 on Town Highway 8, crossing the Black River, Irasburg, Vermont.

[VTAOT, Vermont Agency of Transportation; --, no data]

\begin{tabular}{|c|c|c|c|c|c|c|c|c|c|c|c|}
\hline Description & Station $^{1}$ & $\begin{array}{l}\text { VTAOT } \\
\text { minimum } \\
\text { low-chord } \\
\text { elevation } \\
\text { (feet) }\end{array}$ & $\begin{array}{c}\text { Surveyed } \\
\text { minimum } \\
\text { low-chord } \\
\text { elevation }{ }^{2} \\
\text { (feet) }\end{array}$ & $\begin{array}{c}\text { Bottom of } \\
\text { footing } \\
\text { elevation } \\
\text { (feet) }\end{array}$ & $\begin{array}{c}\text { Channel } \\
\text { elevation at } \\
\text { abutment/ } \\
\text { pier }^{2} \\
\text { (feet) }\end{array}$ & $\begin{array}{l}\text { Contraction } \\
\text { scour depth } \\
\text { (feet) }\end{array}$ & $\begin{array}{l}\text { Abutment } \\
\text { scour } \\
\text { depth } \\
\text { (feet) }\end{array}$ & $\begin{array}{l}\text { Pier } \\
\text { scour } \\
\text { depth } \\
\text { (feet) }\end{array}$ & $\begin{array}{l}\text { Depth of } \\
\text { total scour } \\
\text { (feet) }\end{array}$ & $\begin{array}{c}\text { Elevation of } \\
\text { scour }^{2} \\
\text { (feet) }\end{array}$ & $\begin{array}{c}\text { Remaining } \\
\text { footing/pile } \\
\text { depth } \\
\text { (feet) }\end{array}$ \\
\hline \multicolumn{12}{|c|}{ 500-yr. discharge is 4,460 cubic-feet per second } \\
\hline Left abutment & 0.0 & 739.4 & 1004.8 & -- & 995.6 & 0.0 & 17.3 & -- & 17.3 & 978.3 & -- \\
\hline Right abutment & 66.7 & -- & 1005.3 & -- & 991.8 & 0.0 & 14.8 & -- & 14.8 & 977.0 & -- \\
\hline
\end{tabular}

1. Measured along the face of the most constricting side of the bridge.

2. Arbitrary datum for this study. 


\section{SELECTED REFERENCES}

Arcement, G.J., Jr., and Schneider, V.R., 1989, Guide for selecting Manning's roughness coefficients for natural channels and flood plains: U.S. Geological Survey Water-Supply Paper 2339, 38 p.

Barnes, H.H., Jr., 1967, Roughness characteristics of natural channels: U.S. Geological Survey Water-Supply Paper 1849, 213 p.

Brown, S.A. and Clyde, E.S., 1989, Design of riprap revetment: Federal Highway Administration Hydraulic Engineering Circular No. 11, Publication FHWA-IP-89-016, 156 p.

Federal Highway Administration, 1983, Runoff estimates for small watersheds and development of sound design: Federal Highway Administration Report FHWA-RD-77-158

Froehlich, D.C., 1989, Local scour at bridge abutments in Ports, M.A., ed., Hydraulic Engineering--Proceedings of the 1989 National Conference on Hydraulic Engineering: New York, American Society of Civil Engineers, p. 13-18.

Hayes, D.C.,1993, Site selection and collection of bridge-scour data in Delaware, Maryland, and Virginia: U.S. Geological Survey Water-Resources Investigation Report 93-4017, 23 p.

Interagency Advisory Committee on Water Data, 1982, Guidelines for determining flood flow frequency: U.S. Geological Survey, Bulletin 17B of the Hydrology Subcommittee, $190 \mathrm{p}$.

Laursen, E.M., 1960, Scour at bridge crossings: Journal of the Hydraulics Division, American Society of Civil Engineers, v. 86, no. HY2, p. 39-53.

Richardson, E.V., Harrison, L.J., Richardson, J.R., and Davis, S.R., 1993, Evaluating scour at bridges: Federal Highway Administration Hydraulic Engineering Circular No. 18, Publication FHWA-IP-90-017, 131 p.

Richardson, E.V., Simons, D.B., and Julien, P.Y., 1990, Highways in the river environment: Federal Highway Administration Publication FHWA-HI-90-016.

Ritter, D.F., 1984, Process Geomorphology: W.C. Brown Co., Debuque, Iowa, 603 p.

Shearman, J.O., 1990, User's manual for WSPRO--a computer model for water surface profile computations: Federal Highway Administration Publication FHWA-IP-89-027, 187 p.

Shearman, J.O., Kirby, W.H., Schneider, V.R., and Flippo, H.N., 1986, Bridge waterways analysis model; research report: Federal Highway Administration Publication FHWA-RD-86-108, 112 p.

U.S. Department of Transportation, 1993, Stream stability and scour at highway bridges, Participant Workbook: Federal Highway Administration Publication FHWA HI-91-011.

U.S. Geological Survey, 1986, Irasburg, Vermont 7.5 Minute Series quadrangle map: U.S. Geological Survey Topographic Maps, Scale 1:24,000. 


\section{APPENDIX A: \\ WSPRO INPUT FILE}




\section{WSPRO INPUT FILE}

GR

GR

GR

GR

GR

$\mathrm{N}$

SA

*

XS

GR

GR

GR

GR

GR

GR

GR

$\mathrm{N}$

SA

*

XS

*

BR

GR

GR

GR

CD

$\mathrm{N}$

*

$\mathrm{XR}$

U.S. GEOLOGICAL SURVEY WSPRO INPUT FILE iras020.wsp CREATED ON 19-APR-95 FOR BRIDGE IRASTH00080020 USING FILE iras020.dCa HYDRAULIC ANALYSIS OF IRASO2O OVER THE BLACK RIVER IN COVENTRY, VT

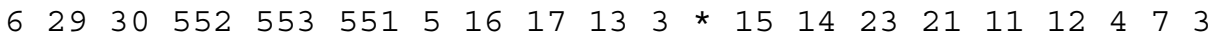

Discharges from the log Pearson type 3 analysis of gage data from station 04296000 Black River at Coventry, VT and adjusted by drainage area relationship

38004460

0.00050 .0005

Valley slope determined from survey data between exit and appr.

Since EXIT1 had been surveyed through as deep section, EXIT2 was surveyed. EXIT2 consisted of only the channel geometry so the overbank sections of EXIT1 were appended to EXIT2. EXIT2 is shallower and better represents the river for starting step-backwater analysis.

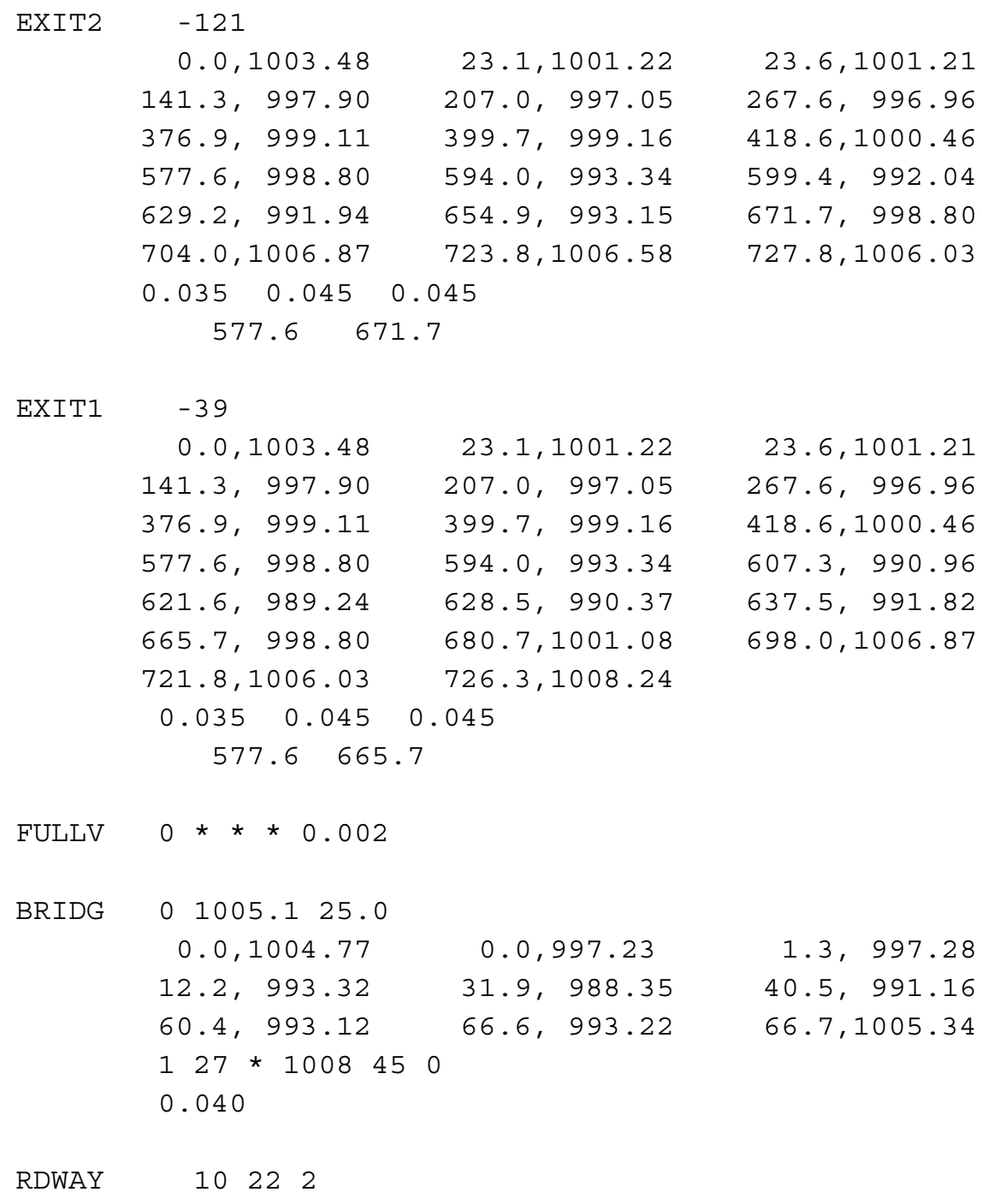


WSPRO INPUT FILE (continued)

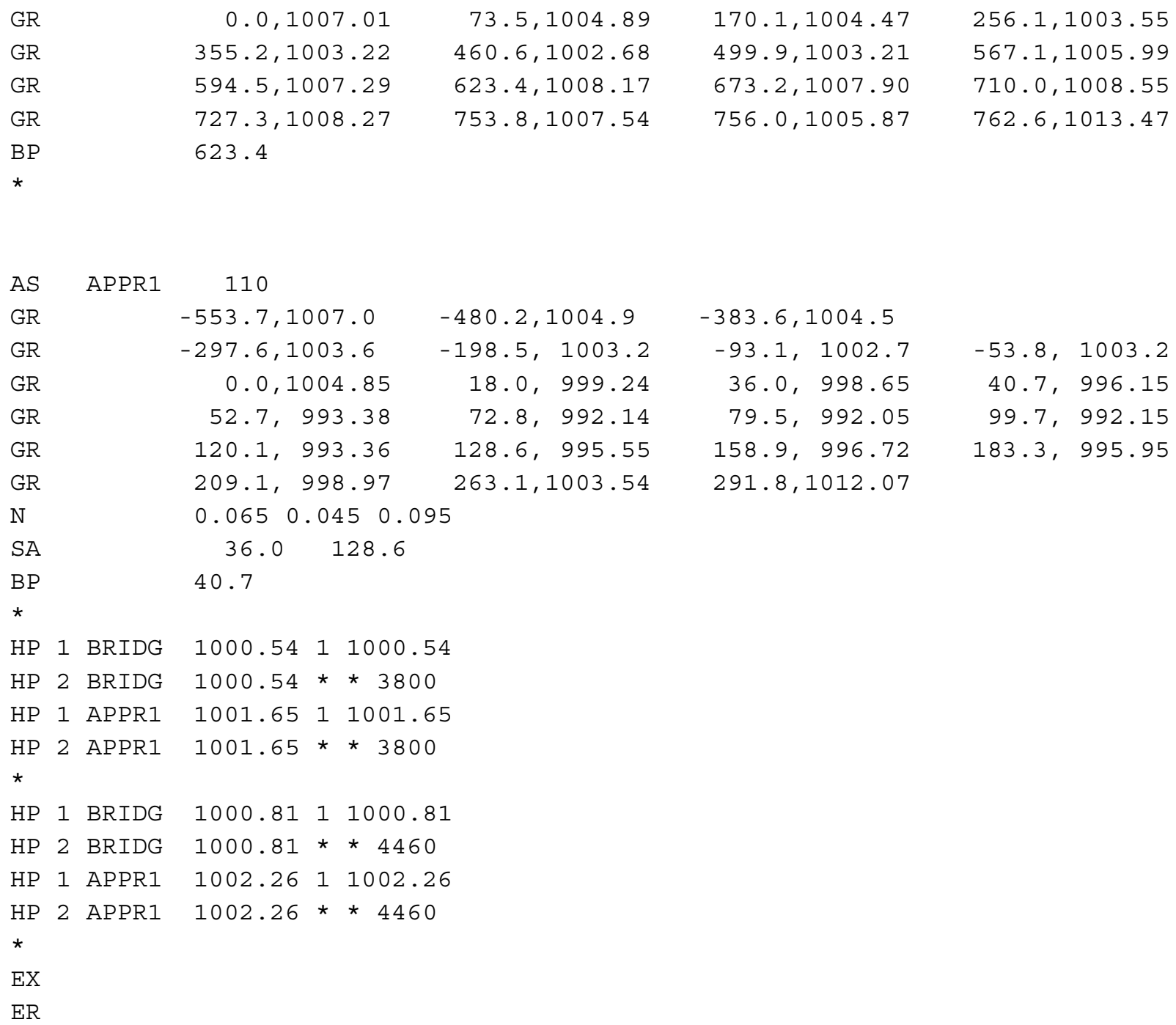




\section{APPENDIX B: \\ WSPRO OUTPUT FILE}




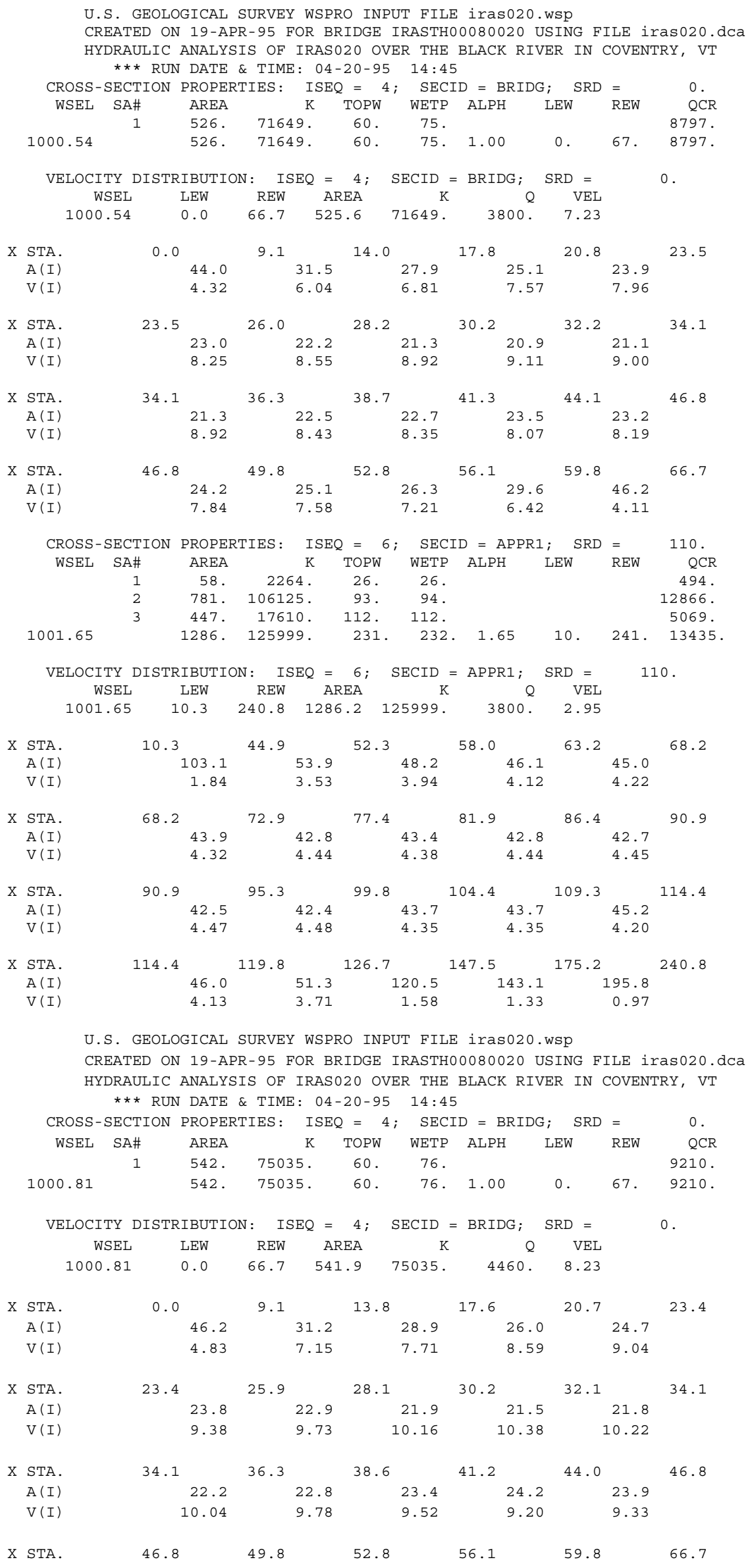


WSPRO OUTPUT FILE (continued)

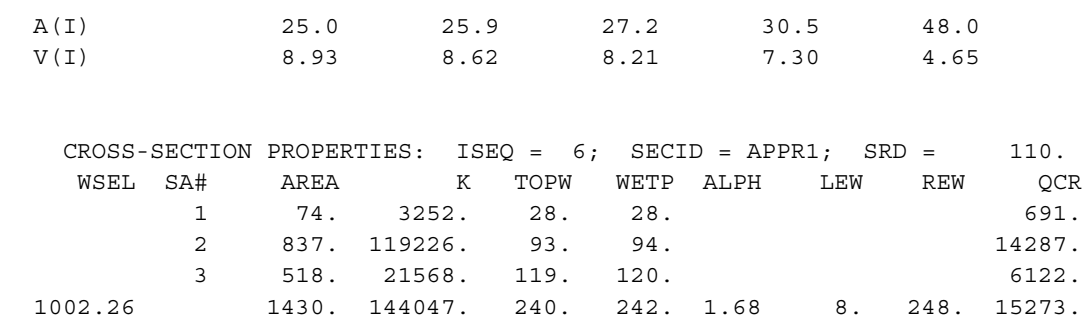

VELOCITY DISTRIBUTION: ISEQ $=6 ;$ SECID $=$ APPR1; $\quad$ SRD $=110$.

\begin{tabular}{|c|c|c|c|c|c|c|c|c|c|}
\hline & WSEI & & LEW & REW & AREA & K & $Q$ & VEL & \\
\hline & 1002.26 & & 8.3 & 248.0 & 1429.6 & 144047 . & 4460 . & 3.12 & \\
\hline $\mathrm{X}$ & STA. & 8.3 & & 43.5 & & .3 & 57.2 & 62.6 & 67.7 \\
\hline & $A(I)$ & & 115.4 & & 59.7 & 52.8 & 50.5 & 49.3 & \\
\hline & $V(I)$ & & 1.93 & & 3.73 & 4.23 & 4.41 & 4.53 & \\
\hline $\mathrm{X}$ & STA. & 67.7 & & 72.7 & & .3 & 81.9 & 86.5 & 91.0 \\
\hline & $A(I)$ & & 48.9 & & 46.6 & 47.2 & 46.6 & 46.5 & \\
\hline & $V(I)$ & & 4.56 & & 4.78 & 4.72 & 4.78 & 4.79 & \\
\hline $\mathrm{X}$ & STA. & 91.0 & & 95.7 & 100 & & 105.1 & 110.1 & 115.5 \\
\hline & $A(I)$ & & 47.2 & & 47.1 & 46.8 & 48.9 & 49.9 & \\
\hline & $V(I)$ & & 4.73 & & 4.74 & 4.77 & 4.56 & 4.47 & \\
\hline $\mathrm{X}$ & STA. & 115.5 & & 121.1 & 128 & & 151.6 & 178.1 & 248.0 \\
\hline & $A(I)$ & & 50.7 & & 56.2 & 145.3 & 153.8 & 220.2 & \\
\hline & $V(I)$ & & 4.40 & & 3.97 & 1.53 & 1.45 & 1.01 & \\
\hline
\end{tabular}

U.S. GEOLOGICAL SURVEY WSPRO INPUT FILE iras020.wsp

CREATED ON 19-APR-95 FOR BRIDGE IRASTH00080020 USING FILE iras020.dCa HYDRAULIC ANALYSIS OF IRASO20 OVER THE BLACK RIVER IN COVENTRY, VT

*** RUN DATE \& TIME: 04-20-95 $14: 45$

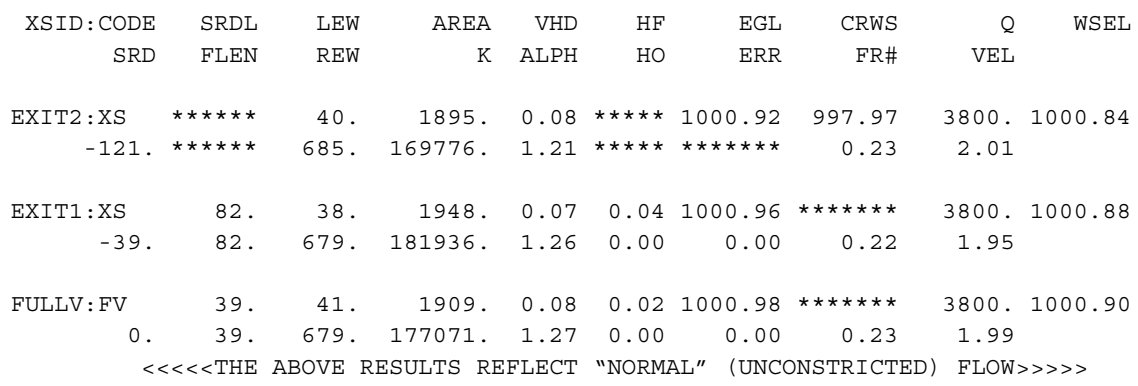


WSPRO OUTPUT FILE (continued)

\begin{tabular}{|c|c|c|c|c|c|c|c|c|}
\hline$M(G)$ & $\mathrm{M}(\mathrm{K})$ & $\mathrm{KQ}$ & XLKQ & XRKQ & \multicolumn{2}{|l|}{ OTEL } & & \\
\hline 0.695 & 0.301 & 87927. & 56. & 123. & \multicolumn{2}{|l|}{1001.57} & & \\
\hline \multirow[b]{2}{*}{ FIRST USER } & & $<<<<<$ END & OF BRIDGE CO & \multicolumn{3}{|c|}{ GE COMPUTATIONS >>>>> } & & \\
\hline & DEFINED & TABLE. & & & & & & \\
\hline XSID : CODE & SRD & LEW & REW & Q & $\mathrm{K}$ & AREA & VEL & WSEL \\
\hline EXIT2:XS & -121 & 40. & 685 & 3800 . & 169776 . & 1895. & 2.01 & 1000.84 \\
\hline EXIT1:XS & -39 & 38. & 679. & 3800. & 181936. & 1948 & 1.95 & 1000.88 \\
\hline FULLV : FV & 0 . & 41. & 679. & 3800 . & 177071. & 1909 & 1.99 & 1000.90 \\
\hline BRIDG : BR & 0 . & 0 . & 67. & 3800 . & 71644. & 526. & 7.23 & 1000.54 \\
\hline RDWAY : RG & 10. * & 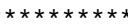 & $\star \star \star \star \star \star *$ & 0. & 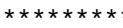 & $\star \star \star \star \star \star \star *$ & $2.00 *$ & $\forall * \star \star \star \star \star \star \star *$ \\
\hline APPRI:AS & 110. & 10. & 241. & 3800 . & 126097 . & 1287 & 2.95 & 1001.65 \\
\hline XSID : CODE & XLKQ & XRKQ & $\mathrm{KC}$ & & & & & \\
\hline APPR $1:$ AS & 56. & 123. & 87927 & & & & & \\
\hline
\end{tabular}

SECOND USER DEFINED TABLE.

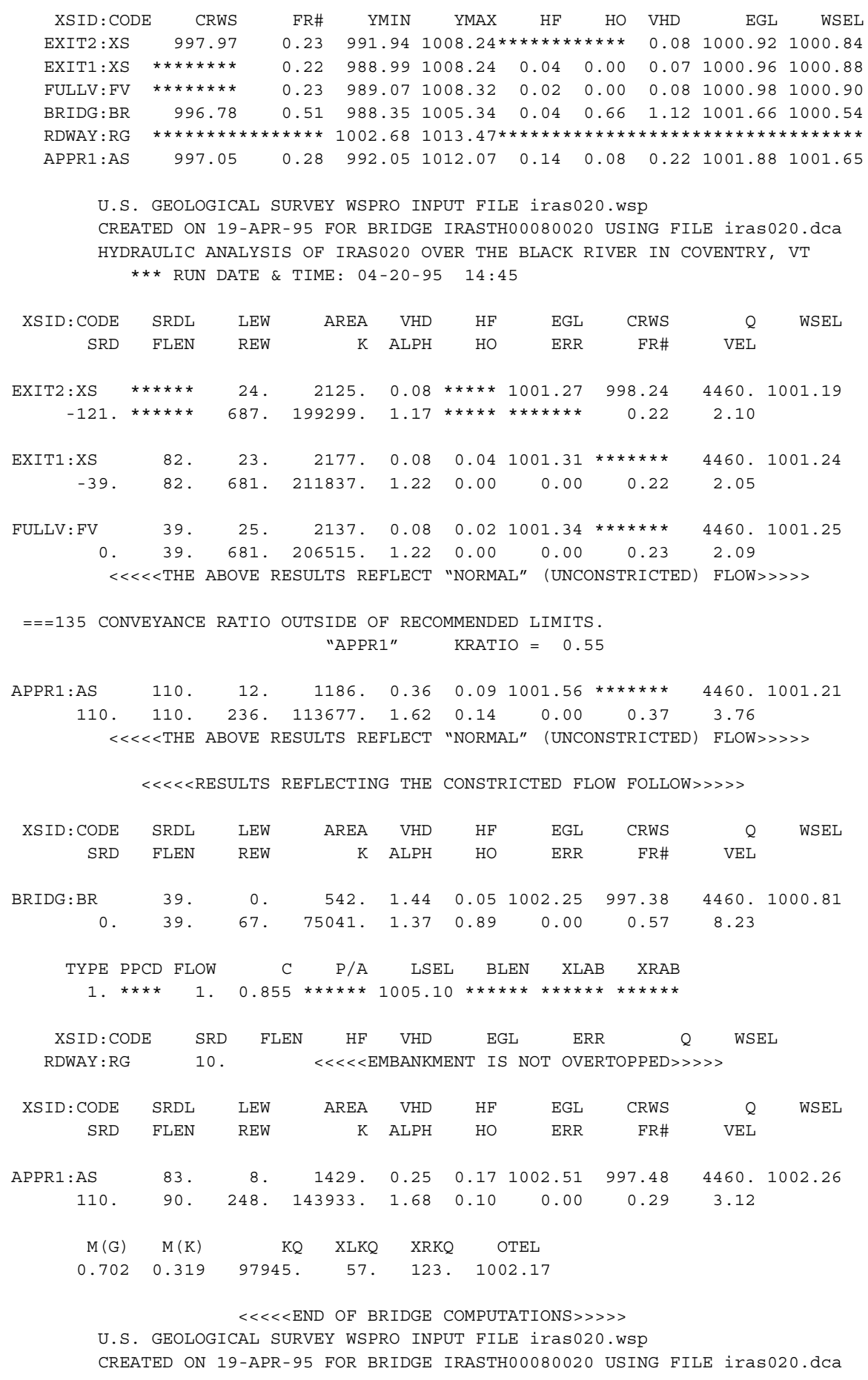




\section{APPENDIX C:}

\section{BED-MATERIAL PARTICAL-SIZE DISTRIBUTION}




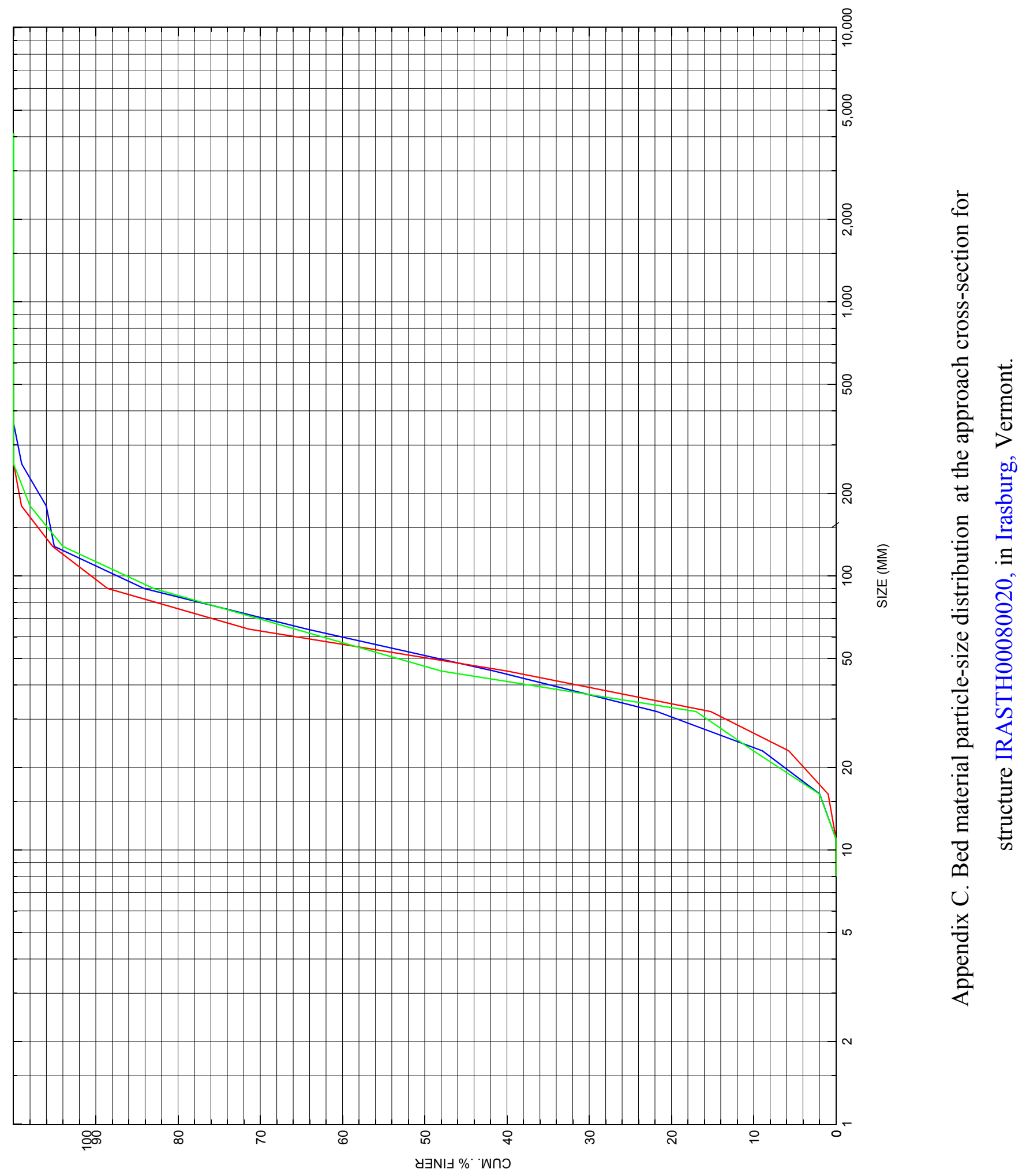




\section{APPENDIX D: \\ HISTORICAL DATA FORM}

